\section{CORNELIUS O'SULLIVAN, F.R.S.}

THE death of Mr. Cornelius O'Sullivan, F.R.S., which took place on January 8 , at the age of sixty-five, has removed from amongst us a worker of great originality who, during the past thirty-five years, made his mark in various branches of pure and applied chemistry connected more or less directly with the industrial processes of brewing.

A native of Bandon, co. Cork, O'Sullivan developed a taste for science at a very early age, and having obtained a scholarship at the Royal School of Mines went through the three years' course with distinction, and became attached to the teaching staff of the Royal College of Chemistry, then in its old quarters in Oxford Street. In I866 he became private assistant to Prof. A. W. von Hofmann, whom he accompanied to Berlin in that year. In the following year he entered the business of Messrs. Bass and Co. at Burton-on-Trent, where he ultimately became the head of the brewing and scientific staff, a post which he occupied up to the time of his death.

When O'Sullivan entered the brewing business the new ideas and discoveries of Pasteur with regard to fermentation were beginning to exercise a marked influence on brewing practice, and there seemed some danger of the new science of bacteriology occupying the field to the exclusion of chemistry. It is the special merit of O'Sullivan that, although very receptive of these new ideas, he clearly recognised that all the biological problems with which the brewer has to deal must ultimately be referred to the chemist, and he therefore set to work, in the first instance, to investigate the nature of starch and the mode in which it is transformed under the hydrolytic agencies of diastase and acids. In these researches O'Sullivan made use of the polarimeter, and by a combination of the optical method with that of cupric reduction he elaborated processes for a study of the gradual disintegration of the starch molecule which have been employed by all subsequent workers. In following the course of the action of diastase on starch, he conclusively proved that the sugar which is formed is not, as was then generally believed, glucose, but a well-defined crystallisable biose, maltose, and that the dextrins which are simultaneously formed consist of several bodies differing amongst themselves by certain well-marked properties. His researches on the influence of temperature on the reaction led to certain valuable practical applications, with which every student of brewing technology is now familiar. The results of O'Sullivan's work on starch were published in the Journal of the Chemical Society between 1872 and 1879 , and constitute a series of memoirs which are justly regarded as classical.

O'Sullivan then turned his attention to the amylans and other carbohydrates of the cereals, and also extended his researches to the gums of the arabin series and to gum tragacanth. Throughout the middle and later period of his life he studied the action of the enzyme invertase on cane-sugar, and in a remarkable memoir published on this subject, in collaboration with Tompson, there is a vast amount of information which seems destined some day to assist in finding a rational explanation of the mechanics of enzyme action.

In 1884 the Chemical Society marked its appreciation of O'Sullivan's work by awarding him the Longstaff medal, and in the following year he was elected a Fellow of the Royal Society.

The varied life-work of O'Sullivan affords an excellent example of the brilliant results which can be attained by the close union of pure science and technology, and of the constant reaction of one on the other. Of all our industries there is not one, with the possible exception of agriculture, which is able to suggest so many problems in chemistry, physics, and biology as the ancient industry of brewing, and no one understood this better than the subject of this brief notice. Of his fine personal qualities and of the influence he had on the younger workers in a field which he made specially his own this is not the place to speak; suffice it to say that his generous, warm-hearted Celtic nature endeared him to a large circle of friends who are now mourning his loss.

\section{NOTES}

THE council of the Royal Astronomical Society has awarded the gold medal of the society to Prof. E. W. Brown, F.R.S., professor of applied mathematics at Haverford College, Pennsylvania, U.S.A., for his researches in the lunar theory.

THE Göttingen Königliche Gesellschaft der Wissenschaften has elected the following foreign members:-Prof. H. A. Lorentz, Leyden; Prof. L. Luciani, Rome; Lord Rayleigh, Pres.R.S., and Prof. C. S. Sherrington, F.R.S.

THE council of the Royal Geographical Society has elected Mr. Roosevelt, President of the United States, an honorary member of the society. President Roosevelt has intimated his acceptance of this distinction.

Prof. E. L. Nichols, professor of physics in Cornell University, has been elected president of the American Association for the Advancement of Science for the meeting to be held next year at Chicago.

M. Bovquet, director of technical instruction to the French Minister of Commerce, has been elected director of the Conservatoire national des Arts et Métiers for a period of eight years from January I last, in succession to M. Chandèze, who has retired.

We learn from the British Medical Journal that the French Government has asked the Pasteur Institute to undertake an inquiry as to the distribution of malaria in various centres of colonisation in Tunis, especially the Béja, Mateur, and Goubellat regions, and as to the means of checking the prevalence of the disease.

THE Geological Society of London will this year award its medals and funds as follows :-Wollaston medal to Prof. W. J. Sollas, F.R.S.; Murchison medal to Mr. Alfred Harker, F.R.S.; Lyell medal to Dr. J. F. Whiteaves, of Ottawa; Wollaston fund to Dr. Arthur Vaughan; Murchison fund to Dr. Felix Oswald; Lyell fund to Mr. T. C. Cantrill and Mr. Thomas Sheppard; the Bigsby medal to Mr. A. W. Rogers, of the South African Museum, Cape Town.

NEW YORK UNIVERSITy has received a gift of about fifteen acres of land adjoining the south line of its grounds. The value of the property is, Science states, said to be between $40,000 l$. and $60,000 l$. From the same source we learn that $\mathrm{Mr}$. Andrew Carnegie has given to the College of Physicians of Philadelphia 20,00ol. toward the erection of its new building, on condition that a like sum be subscribed, of which $16,000 l$. has already been received.

WE announce with regret the death of the Very Rev. Robert H. Story, principal of Glasgow University, on January 13. For twenty-seven years Dr. Story was minister of the parish of Roseneath, and in 1886 he was appointed to the professorship of ecclesiastical history in the University of Glasgow. In 1898 he succeeded the Rev. Dr. NO. I 942 , VOI. 75$]$ 